\title{
Cimnastik Branşında Hakem Olarak da Görev Yapan Antrenörlerin İşe Adanmışlık Düzeylerinin Farklı Değişkenlere Göre Karşılaştırılması
}

\author{
Banu GÜNDOĞAN 1 (D) , A. Azmi YETIM 2 \\ ${ }^{1}$ Avrasya Üniversitesi, Egzersiz ve Spor Bilimleri Bölümü, TRABZON \\ 2 Gazi Üniversitesi, Spor Bilimleri Fakültesi, ANKARA
}

Araştırma Makalesi

DOI:10.53434/gbesbd. 974135

Öz

Bu çalışmanın amacl, cimnastik branşında hakem olarak da görev yapan antrenörlerin işe adanmışlık düzeylerinin çeşitli değişkenler açısından incelenmesidir. Araştırmanın örneklem grubunu Türkiye Cimnastik Federasyonunda antrenör ve hakem olarak görev yapan 2020 yll vizeli 232 birey oluşturmaktadır. Betimsel tarama modelinde yapılan çalışmada veri toplama aracı olarak araștırmacılar tarafindan oluşturulan kişisel bilgi formu ve Schaufeli ve diğerleri (2002) tarafindan geliştirilen, Eryılmaz ve Doğan (2012) tarafindan Türkçe'ye uyarlanmış "Utrecht İşe Adanmışlık Ölçeği" kullanılmıştır. Verilerin analizinde istatistiksel yöntem olarak; tanımlayıcı istatistik ile bağımsız gruplar için T-testi ve Anova testi kullanılmıştır. Sonuç olarak hakem olarak da görev yapan antrenörlerin işe adanmışlık seviyelerinin yüksek düzeyde olduğu ve bunun ekonomik düzey, toplam çalışma saati, mesai dışında çalışma durumu açısından anlamlı şekilde farklılaştı̆ı̆; hakemlik branşı, hakemlik brövesi, antrenörlük süresi ve hakemlik süresi açısından anlamlı şekilde farklılaşmadığı tespit edilmiştir.

Anahtar sözcükler: Cimnastik, Antrenör, Hakem, İșe Adanmışlı 


\title{
Comparison of Work Engagement Levels of Trainers Working as Referees in Gymnastics Branch According to Different Variables
}

\begin{abstract}
The purpose of this study is to determine the work engagement level of the individuals working as gymnastics coaches and referees in the branch of gymnastics in their working life in terms of various variables. The sample group of the research consists of 232 individuals, who serve in the Turkish Gymnastics Federation and have visas for the year 2020 and work as gymnastics coaches and referees. In the study, descriptive scanning design was used. In the research, the personal information form, which was created by the researchers, and Utrecht Work Engagement Scale, which was developed by Schaufeli et al. (2002) and was adapted to Turkish by Eryllmaz ve Doğan (2012) were used as the data collection instruments. In the data analysis, descriptive statistics and t-test and ANOVA test for independent groups were used as the statistical methods. As a result, it was determined that the work engagement level of the individuals working as gymnastics coaches and referees was at a high level and that there is a significant difference in terms of economic level, total working hours, working outside working hours, didn't differ meaningfully in terms of the referee branch, the referee license, coaching time and refereeing time.
\end{abstract}

Keywords: Gymnastics, Coach, Referee, Work Engagement

\section{Giriş}

İşe adanmışlı kavramı günümüzde çok değerli örgütsel çıktılarla ilişkili olduğu keşfedildiği için örgütsel davranış alanındaki çalışmaların ilgi gören bir konusu haline gelmiştir. Çünkü iş yaşamında adanmış̧ık ile ilgili araştırmalarda, adanmış çalışanın daha yüksek personel performansına, daha olumlu bir iş tutumuna sahip olduğu ve işten ayrılma niyetinin daha düşük olduğu sonucuna ulaşılmıştır (Bakker, Schaufeli, Leiter ve Taris, 2008). İşe adanmışlık bir sağlık psikolojisi kavramı olarak ortaya atılmış, içeriği gereği bir sağlıksızlık durumu olan tükenmişliğin zıt olgusu olarak kavramsallaştırılmıştır. Örneğin çalışmaya adanmış olan bireylerde tükenmişlik, depresyon belirtileri, somatik şikayetler ve uyku sorunları gibi sağlık şikayetlerinin olmadığı gözlenmiştir. Bir başka deyişle işe adanmışlık daha çok sağlıklı bireylerde gözlenebilecek bir yaşantıdır (Turgut, 2010). Bunun en büyük nedeni çalışanların yapmış oldukları işe duygusal enerjilerini de katarak büyük bir aşkla çalışmalarıdır (Kahn, 1990). İngilizce terminolojide "Engagement" kavramı nişanlanma anlamına gelmektedir. Bu kelime iş yaşamına uyarlandığında farklı ancak benzer bir anlam kazanmaktadır. İşveren ve çalışan nişanlanma törenine benzer şekilde birbirlerine söz verdikleri bir iş sözleşmesi yapmaktadırlar (Bal, 2008).

İşe adanmışlık işini coşku ile yapma, işini yaparken kendini değerli hissetme, keyif alma, gurur duyma, yaratma, işe inanma hissi gibi içsel motivasyonun temel fonksiyonlarına işaret eden bir kavramdır (Bakker ve diğerleri, 2008; Bersin, 2015; Çetin, Basım ve Aydoğan, 2011; Kaygın ve Bağcıoğlu, 2018; Schaufeli, Bakker ve Salanova, 2006; Sonnentag, 2003; Turgut, 2010; Yavan, 2016; Yılmaz ve Keçecioğlu, 2018). Bu bağlamda işe adanmış bireyler işlerini bilişsel, fiziksel ve duygusal olarak gayret göstererek yaparlar (Kahn, 1990). İşe adanmışlık kişinin başını (bilişsel enerjisini), elini (fiziksel enerjisini) ve kalbini (duygusal) eş zamanlı olarak rol performansına vermesidir. Duygusal adanma, 
bireyin enerjik, heyecanlı bir şekilde çalışmasını; fiziksel adanma, çalışanın tüm enerjisini işi için kullanmasını; bilişsel adanma ise, çalışanın dikkatini, aklını işine vermesini ifade etmektedir (Rich, Lepine ve Crawford, 2010). Bu nedenle anlık ve belirli bir durumdan ziyade sürekli bilişsel, duygusal bir durumu işaret etmektedir (Bal, 2009). Duygu ve davranışları da aktif bir şekilde kullanmayı gerektirir. Böylece birey yaptığı iş ile gurur duyarak onunla duygusal bir bağlantıya girer ve işini gayretle yaptığı için davranışsal olarak da aktiftir (Turgut, 2010).

Her çalışanın iş yaşamındaki motivasyonunu artırıcı etmenleri ve hedefleri farklıdır. Bazı çalışanlar için gelirlerini artırmak, geleceğini garanti altına almak önemliyken bazıları için ise işlerinde mutlu olmak yeterlidir (Barutçugil, 2002). İşiyle bütünleşmiş çalışan işini çok iyi yapma konusunda kendisini işine adadığı için fiziksel çalışma şartları, ücret, terfi ve iş arkadaşları gibi konular önemli olmaktan ziyade daha tali konumdadır (Özyılmaz ve Süner, 2015). Bireylerin günlük yaşamının önemli bir bölümünü işyerinde geçirdiği göz önüne alındığında hem işe hem de örgüte duyulan adanmışlı̆̆ın önemi büyüktür. Türkçe yazında nispeten daha az çalışılan işe adanmışlık kavramının gün geçtikçe daha popüler olacağı ve yapılan çalışma sayısının artacağı düşünülmektedir (Taşlıyan ve Güler, 2020).

Cimnastik, bütün spor dallarına temel oluşturan uluslararası ölçekte en prestijli spor dallarından biridir. Spordaki öncü ülkeler incelendiğinde cimnastiğin bir ülkenin sportif gelişmişliğinin en önemli göstergelerinden biri olduğu söylenebilir (Polat ve Örs, 2018; Türkiye Cimnastik Federasyonu Bülteni, 2020). Artistik cimnastik branşında Dünya Şampiyonu cimnastikçi İbrahim Çolak' ın "50 saniyenin arkasında 19 yıl var” sözünden de cimnastik sporunun çok küçük yaşlardan başlanan, azim, çaba, kararlılık, fedakârlık, gönülden bağlılık gerektiren bir spor olduğu anlaşılmaktadır. Günümüzde 120.000'e ulaşan lisanslı sporcu sayısı ile Türkiye'nin 81 iline yayılmış cimnastik sporunun ana branşlarında sporcuların, antrenörlerin, hakemlerin ve yöneticilerin başarıları artarak devam etmektedir.*

Spor örgütlerine bakıldığında hedeflenen amaçlara ulaşmak için bir çalışan olarak en önemli rolün antrenör ve hakemlerde olduğu söylenebilir. Çünkü sporda çalışma sahasının ön saflarında antrenörler ve hakemler yer almaktadır. Antrenör ve hakemlerin çalışma hayatı birçok unsurdan etkilenebilmektedir. İșe adanmışlık durumları da bunlardan biridir. İşlerine enerji dolu katılımları, işlerinde yüksek düzeyde zihinsel dayanıklılık sergilemeleri, karşılaştığı güçlüklerle mücadele etmeleri ve fiziksel, bilişsel, duygusal olarak kendilerini işlerine adamaları hedeflenen başarıları arttıracaktır. Bu nedenle antrenör ve hakemlerin işe adanmışlık düzeyleri ile sporcuların ve spor örgütlerinin başarısı birbirleri ile doğrudan bağlantılıdır.

\footnotetext{
* Artistik-erkek branșında; Dünya Şampiyonu İbrahim Çolak, Artistik-kadın branșında; Avrupa ikincisi Göksu Üçtaş Şanlı, Ritmik Cimnastik branşında; 2020 Avrupa Şampiyonluğu, ülkemizi olimpiyatlarda üstün başarıları ile temsil eden sporcularımız Tutya Yılmaz, Göksu Üçtaş, Adem Asil, Ahmet Önder, Ferhat Arıcan, İbrahim Çolak ve 2016 yılında Tokyo'da yapılan 81. Dünya Cimnastik Kongresinde Uluslararası Cimnastik Federasyonu Konsey ve Yarışma Komisyonu üyesi seçilerek Avrupa kıtasını temsil hakkını elde etmiş eski şampiyon ve milli sporcu olan Türkiye Cimnastik Federasyonu başkanı Suat Çelen.
} 
Literatürde cimnastik branşında antrenör ve hakemlerin işe adanmışlık düzeyleri üzerine yapılmış çalışmalara rastlanmamıștır. Bunun nedeni bazı spor dallarında hakemlik ve antrenörlük mesleğin bir arada yapılmasına izin verilmemesi olarak değerlendirilebilir. Ancak cimnastik sporunda diğer ülkelerde ve ülkemizde hakemlik ve antrenörlük mesleği birlikte yapılabilmektedir. Cimnastik sporunda hakemlerin çok yönlü değerlendirme yapması (artistik-teknik-uygulama, müzik, ritim, seri bütünlügü, vücut ifadesi, çeşitlilik, koreografinin ana fikri, vücut zorlukları, bağlantılar, reaksiyon çabukluğu ve çevikliği, dinamik değișimler, hareketin kuvveti, yönler ve yörüngeler, alet elementleri, vücut bölümlerinin alet ile koordinasyonu, orijinallik), koreografilerin oldukça karmaşık bir yapıda olması ve uluslararası cimnastik federasyonu (FIG) tarafından kısa süre aralıklarla kuralların güncellenmesi nedeni ile seri hazırlarken sürekli kurallarla iç içe olan hakem olarak görev yapan antrenörler, çok sayıda ve karmaşık olan vücut ve alet elementlerini çok iyi bildikleri ve kurallardaki değişikliklere çabuk adapte oldukları için daha hızlı ve çok yönlü düşünerek kararlar verebilmektedirler.

$\mathrm{Bu}$ çalışmada cimnastik branşında hakem olarak da görev yapan antrenörlerin işe adanmışlık düzeylerinin tespit edilmesi ve işe adanmışlık düzeylerinin çeşitli değişkenler açısından incelenmesi amaçlanmıştır.

\section{Yöntem}

Bu bölümde; araştırmanın evren-örneklemi, veri toplama araçları, verilerin toplanması ve analizi sürecinde yapılan işlemler hakkında bilgiler yer almaktadır.

\section{Araştırmanın Modeli}

Araştırmada evreni temsil eden bireylerden elde edilen veriler ıșığında, evren hakkında genellemeler yapabilme imkânı sağlayan araştırma yöntemi olan betimsel tarama modeli kullanılmıștır (Sönmez ve Alacapınar, 2019).

\section{Çalışma Grubu}

Türkiye Cimnastik Federasyonunda görev yapan 2020 yılı vizeli toplam 460 cimnastik antrenörü araştırmanın evrenini oluştururken, bu grubun içinde yer alan aynı zamanda da hakemlik yapan 232 kişi çalışmanın örneklem grubunu oluşturmaktadır.

\section{Veri Toplama Araçları}

Araștırmada araştırmacılar tarafından geliştiren kişisel bilgi formu ve "Utrecht İşe Adanmışlık Ölçeği" kullanılmıştır. Schaufeli ve diğerleri (2002) tarafından geliştirilen ölçek Eryılmaz ve Doğan (2012) tarafından Türkçe'ye uyarlanmıştır. Ölçeğin 17 madde üç alt boyutu vardır. "İșe İstek Duyma" alt boyutu, çalışanların işlerine karşı hevesli, çalışırken yüksek enerjili ve ruhsal olarak dayanıklı olmaları; "İșe Adanma" alt boyutu, bireylerin işlerini yaparken işleriyle gurur duymaları, işlerini ilham verici olarak algılamaları ve bir amaca hizmet ediyor olarak görmeleri; "İșe Yoğunlaşma" alt boyutu ise bireylerin çalışırken işlerine odaklanmaları, zamanın nasıl geçtiğini anlamamaları, sadece işlerini düşünmeleri anlamına gelmektedir. Ölçek 5’li Likert tipindedir. "Hiç Uygun Değil" (1), "Uygun Değil" (2), 
"Biraz Uygun" (3), "Uygun" (4), "Tamamen Uygun" (5) şeklinde puanlanmaktadır. Ölçekte tersten kodlanan madde bulunmamaktadır. Ölçekten alınan yüksek puanlar işe yüksek adanmışlığın olduğunu göstermektedir. Ölçeğin tamamı için hesaplanan güvenirlik katsayısı .94'tür. Alt boyutlar için elde edilen güvenirlik katsayları ise işe istek duyma alt boyutu için .87, işe adanma alt boyutu için .87 ve işe yoğunlaşma alt boyutu için .84 olarak hesaplanmıştır (Eryllmaz ve Doğan, 2012).

\section{Verilerin Toplanması}

Gönüllü katılımcılara veri toplama araçları hakkında sözlü bilgi verildikten sonra online anket yöntemiyle araştırmanın verileri toplanmıştır.

\section{Verilerin Analizi}

Araştırmada verilerinin değerlendirilmesinde istatistikî yöntem olarak; frekans, yüzde dağılımları, normallik testi, bağımsız gruplar için t-testi ve tek yönlü varyans analizi (ANOVA) kullanılmıștır. Ayrıca tek yönlü varyans analizinde, birimler arası farkların hangi gruplar arasında olduğunu bulmak amacıyla da LSD testi yapılmıştır. Analizlerde anlamlılık düzeyi $\mathrm{p}<0,05$ olarak alınmıştır.

\section{Bulgular}

Çalışmanın bu bölümünde yapılan analizler sonunda elde edilen bulgulara yer verilmiştir.

Tablo 1. Demografik değişkenler

\begin{tabular}{|c|c|c|c|}
\hline & & \\
\hline \multirow{3}{*}{ Cinsiyet } & & & \\
\hline & Kadın & 135 & 58,2 \\
\hline & Erkek & 97 & 41,8 \\
\hline \multirow{5}{*}{ Yaş } & $18-25$ & 22 & 9,5 \\
\hline & $26-33$ & 67 & 28,9 \\
\hline & $34-41$ & 89 & 38,4 \\
\hline & $42-49$ & 42 & 18,1 \\
\hline & 50 ve üzeri & 12 & 5,2 \\
\hline \multirow{2}{*}{ Medeni durum } & Bekar & 99 & 42,7 \\
\hline & Evli & 133 & 57,3 \\
\hline \multirow{6}{*}{ Ĕ̆itim düzeyi } & İlköğretim & 0 & 0,0 \\
\hline & Ortaokul & 1 & 0,4 \\
\hline & Lise & 17 & 7,3 \\
\hline & Lisans & 182 & 78,4 \\
\hline & Yüksek lisans & 28 & 12,1 \\
\hline & Doktora & 4 & 1,7 \\
\hline \multirow{4}{*}{ Antrenörlük süresi } & $0-4$ & 23 & 9,9 \\
\hline & $5-9$ & 65 & 28,0 \\
\hline & $10-14$ & 65 & 28,0 \\
\hline & 15 üst & 79 & 34,1 \\
\hline \multirow{5}{*}{ Ekonomik gelir } & Alt & 17 & 7,3 \\
\hline & Orta-Alt & 44 & 19,0 \\
\hline & Orta & 105 & 45,3 \\
\hline & Orta-Üst & 64 & 27,6 \\
\hline & Üst & 2 & 0,9 \\
\hline \multirow{3}{*}{ Toplam çalışma saati } & 5-36 saat & 81 & 34,9 \\
\hline & $37-68$ saat & 119 & 51,3 \\
\hline & 69 saat ve üzeri & 32 & 13,8 \\
\hline
\end{tabular}




\begin{tabular}{llcc}
\hline \multirow{2}{*}{$\begin{array}{l}\text { Mesai dışında çalışma } \\
\text { durumu }\end{array}$} & Hafta sonları işyerinde çalışıyorum & 104 & 44,8 \\
& Akșamları işyerinde çalışıorum & 27 & 11,6 \\
& Calıșmıyorum & 101 & 43,5 \\
\hline \multirow{4}{*}{ Hakemlik branşıı } & Ritmik Cimnastik & 40 & 17,2 \\
& Artistik Cimnastik-Kadın & 66 & 28,4 \\
& Artistik Cimnastik-Erkek & 55 & 23,7 \\
& Aerobik Cimnastik & 50 & 21,6 \\
& Trampolin Cimnastik & 21 & 9,1 \\
\hline \multirow{4}{*}{ Hakemlik brövesi } & Aday & 44 & 19,0 \\
& Bölge & 54 & 23,3 \\
& Milli & 117 & 50,4 \\
& Uluslararası & 17 & 7,3 \\
\hline \multirow{3}{*}{ Hakemlik süresi } & $0-4$ & 80 & 34,5 \\
& $5-9$ & 66 & 28,4 \\
& $10-14$ & 39 & 16,8 \\
& 15 üst & 47 & 20,3 \\
\hline
\end{tabular}

Tablo 1'e göre 232 katılımcının demografik özellikleri incelendiğinde kadınların oranı \%58,2 iken erkeklerin oranı \%41,8'dir. 34-41 yaş arası olanların oranı \%38,4'tür. Evlilerin oranı \%57,3'tür. Katılımcıların büyük çoğunluğu $(\% 78,4)$ lisans mezunudur. Çalışma süresi 15 yıldan fazla olanların oranı \%34,1'dir. Şu an görev yaptığı kulüpte antrenörlük süresi 5-9 yıl olanların oranı \%35,8'dir. Aylık kazancına göre geliri orta-üst seviyede olan bireylerin oranı \%27,6'dır. Toplam çalışma saati 69 saat ve üzeri olanların oranı \%51,3'dür. Mesai dışında hafta sonları işyerinde çalışanların oranı \%44,8'dir. Ritmik Cimnastik branşında hakemlik yapanların oranı \%17,2; Artistik Cimnastik-kadın branşında hakemlerin oranı \%28,4; Artistik Cimnastik-erkek branşında hakemlerin oranı \%23,7; Aerobik Cimnastik branşında hakemlerin oranı \%21,6; Trampolin Cimnastik branşında hakemlik yapanların oranı \%9,1'dir. Milli hakemlerin oranı \%50,4'tür. Hakemlik süresi 0-4 yıl olanların oranı \%34,5'tir.

Tablo 2: İşe adanmışlı̆̆a ait betimsel istatistikler ve güvenirlik katsayıları

\begin{tabular}{lcccccccc}
\hline & N & Min & Max & Ortalama & Ss & Çarpıklık & Basıklık & $\begin{array}{c}\text { Cronbach's } \\
\text { Alpha }\end{array}$ \\
\hline İșe İstek Duyma & 232 & 2,00 & 5,00 & 4,20 & 0,63 &,- 657 &, 558 &, 841 \\
İșe Adanma & 232 & 2,80 & 5,00 & 4,57 & 0,48 & $-1,186$ & 1,216 &, 827 \\
İșe Yoğunlaşma & 232 & 2,00 & 5,00 & 4,18 & 0,67 &,- 665 &, 126 &, 883 \\
İșe Adanmışlık & 232 & 2,24 & 5,00 & 4,30 & 0,56 &,- 722 &, 575 &, 941 \\
\hline
\end{tabular}

${ }^{*} \mathrm{p}<0,05$

Tablo 2'ye göre çarpıklık ve basıklık değerleri +3 ile -3 arasında bir bulgu sergilediğinden, verilerin homojen dağılım varsayımı kabul edilmiş ve parametrik testler uygulanmıştır (Cohen ve Swerdlik, 2010). Güvenirlik katsayıları incelendiğinde ölçeğin bütünü için bu değer .94 olarak, boyutlar açısından bakıldığında, sırasıyla .84, .82, .88 olarak hesaplanmıştır. 
Araştırmada kullanılan işe adanmışlık ölçeği 5’li Likert tipinde 17 maddeden oluşmaktadır. Katılımcıların bu ölçekten elde edebilecekleri en düşük işe adanmışlık puanı 17 iken, en yüksek 85'tir. Araştırma sonucunda katılımcıların ișe adanmışlık ölçeğine verdikleri cevapların genel toplam puanlarının aritmetik ortalaması 73 olup, genel olarak "yüksek düzeyde $(4,30)$ " işe adanmış oldukları tespit edilmiştir.

Katılımcıların ișe adanmışlıkları alt boyutlara göre incelendiğinde, "ișe istek duyma" alt boyutunda 6 madde $(1,4,8,12,15,17)$ yer almakta olup, alınabilecek en düşük puan 6 , en yüksek puan ise 30 'dur. "İșe istek duyma" alt boyutunun toplam puanlarının aritmetik ortalaması 71 olup, katılımcıların, işe istek duyma alt boyutunda "yüksek düzeyde $(4,20)$ " işe adanmış oldukları tespit edilmiştir. "İşe adanma" alt boyutunda 5 madde $(2,5,7,10,13)$ yer almakta olup, alınabilecek en düşük puan 5, en yüksek puan ise 25'tir. Katılımcıların "işe adanma" alt boyutunun toplam puanlarının aritmetik ortalaması 77 olup, "yüksek düzeyde $(4,57)$ " işe adanmış oldukları tespit edilmiştir. "İşe yoğunlaşma" alt boyutunda 6 madde $(3,6,9,11,14,16)$ yer almakta olup, alınabilecek en düşük puan 6, en yüksek puan ise 30'dur. "İşe yoğunlaşma" alt boyutunun toplam puanlarının aritmetik ortalaması 71 olup, katılımcıların, mesleğe bağlılık boyutunda "yüksek düzeyde $(4,18)$ " işe adanmış oldukları tespit edilmiştir (Tablo 2).

Tablo 3: İșe adanmışlığın ekonomik düzey değişkenine göre ANOVA testi bulguları

\begin{tabular}{|c|c|c|c|c|c|c|c|}
\hline & & $\mathbf{N}$ & Ortalama & Ss & $\mathbf{F}$ & $\mathbf{P}$ & İkili karşılaştırma \\
\hline \multirow{4}{*}{ İşe İstek Duyma } & Alt & 17 & 3,99 & 0,69 & \multirow{4}{*}{9,616} & \multirow{4}{*}{, $000^{*}$} & $1<4$ \\
\hline & Orta-Alt & 44 & 3,98 & 0,74 & & & $2<4$ \\
\hline & Orta & 105 & 4,12 & 0,57 & & & $3<4$ \\
\hline & Orta-Üst-Üst & 66 & 4,52 & 0,49 & & & \\
\hline \multirow{4}{*}{ İşe Adanma } & Alt & 17 & 4,40 & 0,48 & \multirow{4}{*}{2,425} & \multirow{4}{*}{,066 } & \\
\hline & Orta-Alt & 44 & 4,46 & 0,56 & & & \\
\hline & Orta & 105 & 4,59 & 0,46 & & & \\
\hline & Orta-Üst-Üst & 66 & 4,67 & 0,45 & & & \\
\hline \multirow{4}{*}{ İşe Yoğunlaşma } & Alt & 17 & 3,86 & 0,66 & \multirow{4}{*}{5,105} & \multirow{4}{*}{, $002^{*}$} & $1<4$ \\
\hline & Orta-Alt & 44 & 4,02 & 0,75 & & & $2<4$ \\
\hline & Orta & 105 & 4,15 & 0,63 & & & $3<4$ \\
\hline & Orta-Üst-Üst & 66 & 4,41 & 0,60 & & & \\
\hline \multirow{4}{*}{ İşe Adanmışlık } & Alt & 17 & 4,07 & 0,58 & \multirow{4}{*}{6,262} & \multirow{4}{*}{, $000 *$} & $1<4$ \\
\hline & Orta-Alt & 44 & 4,14 & 0,65 & & & $2<4$ \\
\hline & Orta & 105 & 4,27 & 0,52 & & & $3<4$ \\
\hline & Orta-Üst-Üst & 66 & 4,53 & 0,49 & & & \\
\hline
\end{tabular}

${ }^{* \mathrm{p}<0,05}$

Tablo 3'e göre ekonomik düzeyi farklı olan gruplar arasında İşe İstek Duyma, İșe Yoğunlaşma ve İșe Adanmışlık açısından istatistiksel olarak anlamlı farklılık bulunmaktadır $(\mathrm{p}<0,05)$. Ekonomik düzeyi orta-üst ya da üst olanların ortalaması en yüksek iken orta-alt olanların ortalaması en düşüktür. Yapılan ikili karşılaștırma testine göre orta-üst ya da üst olanların ortalaması diğer grupta olanlara göre anlamlı şekilde daha yüksektir. 
Tablo 4: İșe adanmışlığın toplam çalıșma saati değişkenine göre ANOVA testi bulguları

\begin{tabular}{|c|c|c|c|c|c|c|c|}
\hline & & $\mathbf{N}$ & Ortalama & Ss & $\mathbf{F}$ & $\mathbf{P}$ & İkili karşılaștırma \\
\hline \multirow{3}{*}{ İşe İstek Duyma } & 5-36 saat & 81 & 4,07 & 0,58 & \multirow{3}{*}{6,479} & \multirow{3}{*}{, $002^{*}$} & $1<3$ \\
\hline & $37-68$ saat & 119 & 4,20 & 0,67 & & & \multirow[t]{2}{*}{$2<3$} \\
\hline & 69 saat ve üzeri & 32 & 4,54 & 0,47 & & & \\
\hline \multirow{3}{*}{ İşe Adanma } & $5-36$ saat & 81 & 4,56 & 0,44 & \multirow{3}{*}{2,792} & \multirow{3}{*}{, 063} & \\
\hline & 37-68 saat & 119 & 4,53 & 0,53 & & & \\
\hline & 69 saat ve üzeri & 32 & 4,76 & 0,34 & & & \\
\hline \multirow{3}{*}{ İşe Yoğunlaşma } & 5-36 saat & 81 & 4,04 & 0,66 & \multirow{3}{*}{4,092} & \multirow{3}{*}{,018* } & $1<3$ \\
\hline & $37-68$ saat & 119 & 4,21 & 0,68 & & & \\
\hline & 69 saat ve üzeri & 32 & 4,43 & 0,58 & & & \\
\hline \multirow{3}{*}{ İşe Adanmışlık } & $5-36$ saat & 81 & 4,20 & 0,52 & \multirow{3}{*}{4,787} & \multirow{3}{*}{,009* } & $1<3$ \\
\hline & $37-68$ saat & 119 & 4,30 & 0,60 & & & $2<3$ \\
\hline & 69 saat ve üzeri & 32 & 4,56 & 0,44 & & & \\
\hline
\end{tabular}
${ }^{* \mathrm{p}}<0,05$

Tablo 4'e göre toplam çalışma saati farklı olan gruplar arasında İşe İstek Duyma, İşe Yoğunlaşma ve İșe Adanmışlık açısından anlamlı farklılık bulunmaktadır $(\mathrm{p}<0,05)$. Çalışma saati 69 saat ve üzeri olan bireylerin ortalaması en yüksek iken süre azaldıkça ortalama da azalmaktadır. Yapılan ikili karşılaştırma testine göre çalışma saati 69 saat ve üzeri olanların ortalaması diğer grupta olanlara göre anlamlı şekilde daha yüksektir.

Tablo 5: İşe adanmışlığın mesai dışında çalışma durumu değişkenine göre ANOVA testi bulguları

\begin{tabular}{|c|c|c|c|c|c|c|c|}
\hline & & $\mathbf{N}$ & Ort & Ss & $\mathbf{F}$ & $\mathbf{P}$ & $\begin{array}{c}\text { İkili } \\
\text { karşılaştırma }\end{array}$ \\
\hline \multirow{3}{*}{$\begin{array}{l}\text { İşe İstek } \\
\text { Duyma }\end{array}$} & $\begin{array}{l}\text { Hafta sonları işyerinde } \\
\text { çalıșıyorum }\end{array}$ & 104 & 4,31 & 0,65 & \multirow{3}{*}{8,044} & \multirow{3}{*}{, $000^{*}$} & $1>3$ \\
\hline & Akşamları işyerinde çalışıyorum & 27 & 4,44 & 0,46 & & & $2>3$ \\
\hline & Çalıșmiyorum & 101 & 4,02 & 0,60 & & & \\
\hline \multirow{3}{*}{ İșe Adanma } & $\begin{array}{l}\text { Hafta sonları işyerinde } \\
\text { çalışıyorum }\end{array}$ & 104 & 4,59 & 0,54 & \multirow{3}{*}{0,807} & \multirow{3}{*}{448} & \\
\hline & Akşamları işyerinde çalıșıyorum & 27 & 4,65 & 0,37 & & & \\
\hline & Çalıșmiyorum & 101 & 4,53 & 0,46 & & & \\
\hline \multirow{3}{*}{$\begin{array}{l}\text { İşe } \\
\text { Yoğunlaşma }\end{array}$} & $\begin{array}{l}\text { Hafta sonları işyerinde } \\
\text { çalışıyorum }\end{array}$ & 104 & 4,33 & 0,64 & \multirow{3}{*}{9,499} & \multirow{3}{*}{, $000^{*}$} & $1>3$ \\
\hline & Akşamları işyerinde çalıșıyorum & 27 & 4,38 & 0,54 & & & $2>3$ \\
\hline & Çalıșmiyorum & 101 & 3,97 & 0,68 & & & \\
\hline \multirow{3}{*}{$\begin{array}{l}\text { İșe } \\
\text { Adanmışlık }\end{array}$} & $\begin{array}{l}\text { Hafta sonları işyerinde } \\
\text { çalıșıyorum }\end{array}$ & 104 & 4,40 & 0,58 & \multirow{3}{*}{6,767} & \multirow{3}{*}{, $001^{*}$} & $1>3$ \\
\hline & Akşamları işyerinde çalışıyorum & 27 & 4,48 & 0,43 & & & $2>3$ \\
\hline & Çalıșmiyorum & 101 & 4,15 & 0,54 & & & \\
\hline
\end{tabular}

$* \mathrm{p}<0,05$

Tablo 5'e göre mesai dışında çalışma durumu farklı olan gruplar arasında İșe İstek Duyma, İşe Yoğunlaşma ve İşe Adanmışlık açısından anlamlı farklılık bulunmaktadır $(\mathrm{p}<0,05)$. Akşamları işyerinde çalışanların ortalaması en yüksek iken çalışmayanların ortalaması en düşüktür. Yapılan ikili karşılaştırma testine göre hafta sonları ya da akşamları işyerinde çalışanların ortalaması çalışmayanlara göre anlamlı şekilde daha yüksektir. 
Tablo 6: İșe adanmışlığın hakemlik yapılan branș değișkenine göre ANOVA testi bulguları

\begin{tabular}{|c|c|c|c|c|c|c|}
\hline & & $\mathbf{N}$ & Ortalama & Ss & $\mathbf{F}$ & $\mathbf{P}$ \\
\hline \multirow{5}{*}{ İşe İstek Duyma } & Ritmik Cimnastik & 40 & 4,40 & 0,60 & \multirow{5}{*}{1,635} & \multirow{5}{*}{ 166 } \\
\hline & Artistik Cimnastik-Kadın & 66 & 4,23 & 0,62 & & \\
\hline & Artistik Cimnastik-Erkek & 55 & 4,15 & 0,69 & & \\
\hline & Aerobik Cimnastik & 50 & 4,12 & 0,54 & & \\
\hline & Trampolin Cimnastik & 21 & 4,04 & 0,72 & & \\
\hline \multirow{5}{*}{ İșe Adanma } & Ritmik Cimnastik & 40 & 4,60 & 0,53 & \multirow{5}{*}{0,586} & \multirow{5}{*}{ 673 } \\
\hline & Artistik Cimnastik-Kadın & 66 & 4,59 & 0,48 & & \\
\hline & Artistik Cimnastik-Erkek & 55 & 4,49 & 0,53 & & \\
\hline & Aerobik Cimnastik & 50 & 4,59 & 0,43 & & \\
\hline & Trampolin Cimnastik & 21 & 4,64 & 0,43 & & \\
\hline \multirow{5}{*}{ İșe Yoğunlaşma } & Ritmik Cimnastik & 40 & 4,27 & 0,68 & \multirow{5}{*}{0,990} & \multirow{5}{*}{,414 } \\
\hline & Artistik Cimnastik-Kadın & 66 & 4,22 & 0,66 & & \\
\hline & Artistik Cimnastik-Erkek & 55 & 4,15 & 0,66 & & \\
\hline & Aerobik Cimnastik & 50 & 4,19 & 0,62 & & \\
\hline & Trampolin Cimnastik & 21 & 3,93 & 0,78 & & \\
\hline \multirow{5}{*}{ İşe Adanmışlık } & Ritmik Cimnastik & 40 & 4,41 & 0,58 & \multirow{5}{*}{0,795} & \multirow{5}{*}{,529 } \\
\hline & Artistik Cimnastik-Kadın & 66 & 4,33 & 0,55 & & \\
\hline & Artistik Cimnastik-Erkek & 55 & 4,25 & 0,60 & & \\
\hline & Aerobik Cimnastik & 50 & 4,29 & 0,49 & & \\
\hline & Trampolin Cimnastik & 21 & 4,18 & 0,63 & & \\
\hline
\end{tabular}
$\overline{{ }^{\mathrm{p}}<0,05}$

Tablo 6'ya göre hakemlik yaptı̆̆ı branşı farklı olan gruplar arasında İşe Adanmışlık ve alt boyut puanları açısından anlamlı farklılık bulunmamaktadır ( $p>0,05)$.

Tablo 7: İșe adanmışlığın hakemlik brövesi değişkenine göre ANOVA testi bulguları

\begin{tabular}{|c|c|c|c|c|c|c|}
\hline & & $\mathbf{N}$ & Ortalama & Ss & $\mathbf{F}$ & $\mathbf{P}$ \\
\hline \multirow{4}{*}{ İşe İstek Duyma } & Aday & 44 & 4,26 & 0,69 & \multirow{4}{*}{,669 } & \multirow{4}{*}{, 572} \\
\hline & Bölge & 54 & 4,25 & 0,52 & & \\
\hline & Milli & 117 & 4,14 & 0,66 & & \\
\hline & Uluslararası & 17 & 4,27 & 0,57 & & \\
\hline \multirow{4}{*}{ İşe Adanma } & Aday & 44 & 4,69 & 0,42 & \multirow{4}{*}{1,215} & \multirow{4}{*}{,305 } \\
\hline & Bölge & 54 & 4,56 & 0,48 & & \\
\hline & Milli & 117 & 4,55 & 0,50 & & \\
\hline & Uluslararası & 17 & 4,46 & 0,56 & & \\
\hline \multirow{4}{*}{ İşe Yoğunlaşma } & Aday & 44 & 4,29 & 0,60 & \multirow{4}{*}{,909 } & \multirow{4}{*}{437} \\
\hline & Bölge & 54 & 4,22 & 0,68 & & \\
\hline & Milli & 117 & 4,11 & 0,71 & & \\
\hline & Uluslararası & 17 & 4,24 & 0,45 & & \\
\hline \multirow{4}{*}{ İşe Adanmışlık } & Aday & 44 & 4,40 & 0,54 & \multirow{4}{*}{,764 } & \multirow{4}{*}{, 515} \\
\hline & Bölge & 54 & 4,33 & 0,53 & & \\
\hline & Milli & 117 & 4,25 & 0,60 & & \\
\hline & Uluslararası & 17 & 4,31 & 0,49 & & \\
\hline
\end{tabular}

${ }^{* \mathrm{p}}<0,05$

Tablo 7'ye göre hakemlik brövesi farklı olan gruplar arasında İşe Adanmışlık ve alt boyut puanları açısından anlamlı farklılık bulunmamaktadır ( $p>0,05)$. 
Tablo 8: İșe adanmışlı̆ıı hakemlik süresi değișkenine göre ANOVA testi bulguları

\begin{tabular}{|c|c|c|c|c|c|c|}
\hline & & $\mathbf{N}$ & Ortalama & Ss & $\mathbf{F}$ & $\mathbf{P}$ \\
\hline \multirow{4}{*}{ İşe İstek Duyma } & $0-4$ & 80 & 4,19 & 0,60 & \multirow{4}{*}{,275 } & \multirow{4}{*}{,843 } \\
\hline & $5-9$ & 66 & 4,24 & 0,59 & & \\
\hline & $10-14$ & 39 & 4,13 & 0,74 & & \\
\hline & 15 üst & 47 & 4,23 & 0,64 & & \\
\hline \multirow{4}{*}{ İşe Adanma } & $0-4$ & 80 & 4,61 & 0,44 & \multirow{4}{*}{2,546} & \multirow{4}{*}{,057 } \\
\hline & $5-9$ & 66 & 4,64 & 0,41 & & \\
\hline & $10-14$ & 39 & 4,38 & 0,62 & & \\
\hline & 15 üst & 47 & 4,57 & 0,51 & & \\
\hline \multirow{4}{*}{ İşe Yoğunlaşma } & $0-4$ & 80 & 4,16 & 0,64 & \multirow{4}{*}{ 901 } & \multirow{4}{*}{, 441 } \\
\hline & $5-9$ & 66 & 4,28 & 0,61 & & \\
\hline & $10-14$ & 39 & 4,07 & 0,80 & & \\
\hline & 15 üst & 47 & 4,16 & 0,67 & & \\
\hline \multirow{4}{*}{ İşe Adanmışlık } & $0-4$ & 80 & 4,30 & 0,53 & \multirow{4}{*}{884} & \multirow{4}{*}{, 450 } \\
\hline & $5-9$ & 66 & 4,37 & 0,50 & & \\
\hline & $10-14$ & 39 & 4,19 & 0,70 & & \\
\hline & 15 üst & 47 & 4,30 & 0,58 & & \\
\hline
\end{tabular}

${ }^{*} \mathrm{p}<0,05$

Tablo 8'e göre hakemlik süresi farklı olan gruplar arasında İşe Adanmışlık ve alt boyut puanları açısından anlamlı farklılık bulunmamaktadır ( $p>0,05)$.

Tablo 9: İșe Adanmışlığın antrenörlük süresi değişkenine göre ANOVA testi bulguları

\begin{tabular}{lllcccc}
\hline & & N & Ortalama & Ss & F & P \\
\hline \multirow{3}{*}{ İşe İstek Duyma } & $0-4$ & 23 & 4,09 & 0,66 & & \\
& $5-9$ & 65 & 4,25 & 0,54 &, 406 &, 749 \\
& $10-14$ & 65 & 4,19 & 0,71 & & \\
\hline \multirow{3}{*}{ İse Adanma } & 15 üst & 79 & 4,19 & 0,63 & & \\
& $0-4$ & 23 & 4,57 & 0,46 & & \\
& $5-9$ & 65 & 4,61 & 0,40 &, 293 &, 830 \\
& $10-14$ & 65 & 4,53 & 0,56 & & \\
İşe Yoğunlaşma & 15 üst & 79 & 4,57 & 0,49 & & \\
& $0-4$ & 23 & 4,07 & 0,74 & & \\
& $5-9$ & 65 & 4,20 & 0,58 &, 324 &, 808 \\
& $10-14$ & 65 & 4,22 & 0,73 & & \\
İş̧e Adanmıșlık & 15 üst & 79 & 4,16 & 0,66 & & \\
& $0-4$ & 23 & 4,23 & 0,59 & & \\
& $5-9$ & 65 & 4,34 & 0,48 &, 244 &, 866 \\
& $10-14$ & 65 & 4,30 & 0,64 & & \\
\hline
\end{tabular}

${ }^{* \mathrm{p}<0,05}$

Tablo 9'a göre antrenörlük süresi farklı olan gruplar arasında İşe Adanmışlık ve alt boyut puanları açısından anlamlı farklılık bulunmamaktadır ( $p>0,05)$. 


\section{Tartışma ve Sonuç}

Cimnastik branşında hakem olarak da görev yapan antrenörlerin işe adanmışlık düzeylerinin incelendiği bu araştırma sonucunda elde edilen bulgular bu bölümde yorumlanmış ve ilgili literatür ile desteklenmiştir. Sonuç olarak katılımcıların işe adanmışlık seviyelerinin "yüksek düzeyde $(4,30)$ " olduğu sonucuna ulaşılmıştır. Alt boyutlara göre incelendiğinde, "ișe istek duyma" alt boyutunda "yüksek düzeyde $(4,20)$ ", "işe adanma" alt boyutunda "yüksek düzeyde $(4,57)$ " ve "İşe yoğunlaşma" alt boyutunda "yüksek düzeyde $(4,18)$ " işe adanmış oldukları tespit edilmiştir (Tablo 2). Diğer bir ifadeyle katılımcıların işlerinde enerjik, tamamen yoğunlaşarak, aşkla çalıştıkları, yüksek iş doyumuna sahip oldukları, hedeflenen başarılara ulaşmak için iş dışı yaşamdan fedakârlık yaptıkları, işlerini hayatlarının merkezine koydukları, mesleğin gerekliliklerini yerine getirdikleri, gönüllü olarak çaba gösterdikleri söylenebilir. Bu bağlamada işine adanmış antrenör ve hakemlerin çalıştığı kurumun iklimine ve sporcularına pozitif katkı sağlayacağı ifade edilebilir. Bu nedenle antrenör ve hakemlerin işe adanmışlık düzeylerinin yükseltmek için programlar geliştirilebilir.

Literatürde antrenör ve hakemlerin işe adanmışlıkları ile ilgili araştırmalara rastlanmadığı için çeşitli mesleklerdeki çalışmalar gözden geçirilmiştir. Aslantaş'ın (2016) banka çalışanları üzerine yaptığı çalışmasında çalışanların işlerini ilginç ve özel olarak buldukları, işlerinin kendilerine çalışma şevki verdiği ve bir anlam taşıdığı, işleriyle gurur duydukları, kendilerini işlerine adadıkları sonucuna ulaşılmıştır. Hoş ve Oksay (2015) hemşireler üzerine yaptığı çalışmasında örgütsel adanmışlık, iş doyumu ve alt boyutlarında pozitif yönlü, anlamlı ve yüksek düzeyde ilişki olduğunu tespit etmiştir. Cengiz, Turgut ve Kabakçı (2016) BESYO öğretim elemanlarının adanmışlık düzeylerini belirlemek için yaptıkları çalışmalarında sadece araştırma görevlilerinin örgütlerine karşı yüksek düzeyde adanmışlık hissettikleri sonucuna ulaşmışlardır. Tokmak (2019) ise üst yönetimin desteklediği çalışanların işe adanmışlık düzeylerinin daha yüksek olduğunu tespit etmiştir. Aynı şekilde Kozikoğlu ve Özcanlı (2020) öğretmenlerin, Canlı (2020) okul yöneticileri ve öğretmenlerin genel adanmışlık düzeylerinin çok yüksek düzeyde olduğu sonucuna ulaşırken yine bir başka benzer çalışmada ise Demir (2020) ilkokulda çalışan öğretmenlerin örgütsel adanmışlıklarının orta düzeyde olduğu sonucuna ulaşmıştır. Literatürde farklılık gösteren çalışmalar da mevcuttur. Yıluzar (2016) sağlık çalışanları üzerine yaptığı araştırmasında; bireylerin işlerine adanmışlık düzeylerinin oldukça düşük olduğunu tespit etmiştir. Aynı şekilde Aydemir ve Endirlik'in (2019) araştırmasında da örnekleme dâhil edilen banka çalışanlarının işe adanmışlık ortalamaları düşük çıkmıştır. $\mathrm{Bu}$ tespitler araştırma sonuçlarıyla farklılık göstermektedir. Aktaş ve Akdemir (2019) ise bu sonuçlardan araştırmalarında çalışanların ancak \%20'sinin işine aktif adanmış, \%20'sinin adanmışlık boşluğunda olduğu yani adanmamış, \%60'lık bölümün tarafsız durumda olduğu sonucuna ulaşmışlardır. İșe adanmışlıkla ile ilgili literatürdeki farklı meslekler üzerine yapılmış araştırmalar incelendiğinde çalışanların işe adanmışlık düzeyi ile ilgili ortak bir yargının oluşmadığı ve araştırmaların antrenörlük, hakemlik gibi yoğun tempoda, uzun saatler çalışılan, fiziksel, bilişsel, duygusal olarak işe adamayı gerektiren öğretmenlik, bankacılık, sağlık alanındaki mesleklerde yoğunlaştığı görülmektedir. 
Günümüzde işe adanmışlık kavramı çalıșma psikolojisi alanında popülerliği artarak devam etmesine rağmen spor bilimleri alanında sadece sporcu adanmışlığı/bağlılığı konusu ile ilgili çalışmalar yapılmıştır (Gülen, Madak, Kumartaşlı ve Sönmez, 2017; Kelecek ve Göktürk, 2017; Kelecek ve Koruç, 2018; Yerlikaya, 2019). Kelecek ve Koruç (2018) çalışmasında futbolcuların sportif yaşamlarında hissettikleri heyecan ve enerjinin azalmasının hem duygusal hem de fiziksel yönden kendilerini tükenmiş hissetmelerine neden olabileceğini ifade etmiştir.

Mevcut araştırma bulgularına göre çalışanların geliri arttıkça işe adanmışlık seviyesinin yükseldiği tespit edilmiștir (Tablo 3). Bireyler arasındaki gelir farklılıkları temel ihtiyaçların karşılanması, istenilenlerin satın alınması açısından farklılıklar oluşturacağı için işe karşı olumlu ya da olumsuz, duygulara yol açabilmektedir. Karaçam ve Pulur (2018) çalışmasında kazandığı ücretten memnun olanların basketbol ve futbol hakemlerinin mesleki haz düzeylerinin daha yüksek olduğunu ifade etmiştir. Literatürde antrenör ve hakemlerin işe adanmışlık düzeyleri ile gelir arasındaki ilişkiyi inceleyen çalışmalara rastlanmamıștır. Ancak Yerlikaya (2019) sporcu adanmışlığı/bağlılığı üzerine yapmış olduğu çalışmasında orta ve yüksek seviye sosyoekonomik statüye sahip olduklarını belirten bisikletçilerde sosyoekonomik statüsü ile sporcu bağlılıkları arasında istatistiksel olarak anlamlı fark tespit etmiştir. Bu sonuçlar mevcut araştırma sonuçları ile farklılık göstermektedir. Literatürde farklı iş sahaları üzerine yapılmış çalışmalarda işe adanmışlık üzerinde gelirin önemli bir faktör olduğu belirlenmiştir. Sarıkaya (2016) otizmli çocuklarla çalışan öğretmenler üzerine yaptığı çalışmasında aldığı ücretten kesinlikle memnun olduğunu belirtenlerin en yüksek işe adanmışlığa sahip olduğunu tespit etmiştir. Tokmak (2019) çalışmasında orta gelir seviyesinde olanların işe adanmışlık düzeylerinin daha düşük olduğunu belirtmiştir. Aydemir (2018) ise inşaat sektöründe çalışanların \%80'inin asgari gelirle çalıştığı ve düşük gelir düzeyine bağlı bu durumun işe adanmayı olumsuz etkilediği sonucuna varmıștır. Yine bir başka benzer çalışmada Şahinbaş (2018) sağlık çalışanlarının işe adanmışlık seviyelerinin aylık gelir durumuna göre farklılık gösterdiği ve buna göre geliri 3000 TL ve üzeri olanların, 2000-2999 TL olanlara göre işe adanmışlık düzeylerinin daha yüksek olduğu sonucuna ulaşmıştır. Çalışma yaşamında çok emek, fazla mesai karşılığında düşük gelir elde etme çalışanların işe adanmışlığını olumsuz yönde etkileyen en önemli nedenlerden biri olarak söylenebilir. Farklı olarak sporcu adanmışlığı üzerine araştırma yapan Gülen ve diğerleri (2017) yaptıkları analizler sonucunda çalışmalarında gelirin adanmışlık üzerindeki etkisinin anlamlı olmadığının belirlenmesi araştırma sonucu ile farklılaşmaktadır.

Katılımcıların toplam çalışma süresi arttıkça işe istek duyma, işe yoğunlaşma alt boyutları ve işe adanmışlık düzeyleri de yükselmektedir (Tablo 4). Cimnastik sporunda antrenman saatleri çok uzun olduğu için işe yoğunlaşmanın artması normal olarak değerlendirilebilir. İlgili literatürde farklı alanlarda çalışanların işe adanmışlık düzeyleri üzerine yapılan araştırmalarda farklı sonuçlara da ulaşılmıştır. Örneğin, Schaufeli (2018) ülke düzeyinde çalışanların adanmışlık düzeyinin haftalık çalışma saati ile negatif ilişkili olduğu sonucuna varmıștır. Doğu ve Güney Avrupa'da işyerinde daha uzun saatler çalışanların işe adanmışlıklarının daha düşük olduğunu; Kuzey ve Kuzeybatı Avrupa'daki 
gibi yüksek verimliliğe sahip ülkelerde ise çalışanların işe adanmışlık düzeylerinin daha yüksek olduğunu tespit etmiştir (Taşliyan ve Güler, 2020).

Araştırma bulgularına göre hafta sonları ya da akşamları işyerinde çalışanların yüksek düzeyde işe adanmış oldukları tespit edilmiştir (Tablo 5). Antrenörlük, hakemlik süresi ve branşın işe adanmışlık üzerindeki etkisinin anlamlı olmaması ancak toplam çalışma saati ve hafta sonları ya da akşamları işyerinde çalışmanın işe adanmışlık üzerindeki etkisinin anlamlı olduğu göz önünde bulundurulduğunda, cimnastik antrenörü ve hakemi olarak görev yapan bireylerin işe adanmışlık düzeylerini etkileyen en önemli faktörün, bu spora ayırdıkları zaman olduğu kanısına varılmaktadır. Cimnastik sporunda çok uzun saat, hafta sonları ve akşamları da devam eden antrenmanların antrenör ve hakem olarak çalışan bireylerin enerjilerini, yoğunlaşma düzeylerini olumsuz etkilemediğini aksine gurur duyma, yaratma hissi ile uzun saatler keyif alarak çalıştıklarını, yaşamlarının merkezine işlerini koyduklarını söylenebilir. Kelecek, Kara ve Aşçı (2014) çalışmasında hakemlerin mesleklerini severek yapmalarının; yaşam ve iş doyumlarını arttırdığını, mesleklerini hayatlarının odak noktası haline getirmelerinin ise iş ve yaşam doyumlarını etkilemediği sonucuna ulaşmıștır. Ancak literatürde ișe adanmışlık ile mesai dışında çalışma durumunu karşılaştıran bir çalışmaya rastlanmamıştır.

Araștırma bulgularına göre katılımcıların işe adanmışlık seviyeleri branş değişkenine göre farklılaşmamaktadır (Tablo 6). Diğer bir ifadeyle branşları Ritmik, Artistik-erkek, Artistik-kadın, Trampolin ve Aerobik cimnastik olan bireylerin benzer işe adanmışlık seviyesinde oldukları ifade edilebilir. Alan yazında işe adanmışlık ile ilgili çalışmaların odağını genelde öğretmenlerin mesleğe adanmışlıkları oluşturmaktadır (Sarıbaş, Akça ve Meydan, 2010). Bireylerin fiziksel, zihinsel ve duygusal gelişimlerde daha çok etkili olan öğretmenlik, antrenörlük gibi mesleklerin doğasında zaten işe adanmışlığın var olması neden olarak düşünülebilir. Literatürde farklı mesleklerin işe adanmışlık düzeyleri karşılaştırılmış ve yaygın olarak branşa göre bir farklılaşma olduğu sonucuna ulașılmıştır. Güner (2006), Kozikoğlu ve Özcanlı (2020) öğretmenlerin mesleğe adanmışlıklarının branşa göre farklılaşmadığı sonucuna ulaşırken, Aydemir (2018) ulaştırma ve depolama alanında çalışanların işe adanmışlıklarının inşaat alanında çalışanlardan daha yüksek olduğunu tespit etmiştir. Göktepe (2016) çalışmasında bankada çalışan beyaz yakalı iş görenlerin işe adanmışlık düzeylerinin yüksek olduğu sonucuna ulaşmıştır. Şahinbaş (2018) çalışmasında hemşire ve doktorların işe adanmışlık seviyelerinin, idari ve diğer sağlık personeline göre daha yüksek olduğu bulgusuna ulaşmıştır. Durgut ve Günay (2020) yapı malzemeleri sektöründeki bir firma çalışanlarının görüşleri alarak gerçekleştirdiği çalışmasında "işyerindeki pozisyon" açısından işe adanmışlığın anlamlı farklılık gösterdiğini tespit etmiştir. Benzer şekilde Ekinci (2012) ortaöğretim okulu öğretmenleri üzerine yaptığı araştırmasında güzel sanatlar ve beden eğitimi öğretmenlerinin fen bilimleri ve yabancı dil branş öğretmenlerine göre genel adanmışlıklarının daha yüksek düzeyde olduğu sonucuna ulaşmıştır. Literatürde farklı spor branşlarında antrenör ve hakemlerin işe adanmışlığı ile ilgili çalışmaların olmaması karşılaştırma yapmayı güçleştirmektedir. Oysaki spor bilimleri alanında "işe adanma" kavramı düşünüldüğünde ilk akla gelen isimlerin işin mutfağında bulunan, sporcularla daha fazla iç içe olan 
antrenörler ve hakemler olduğu söylenebilir. Bununla birlikte alan yazında "sporcu adanmışlığı/bağlılığı" ile ilgili az sayıda çalıșmaya rastlanmıştır. Kelecek ve Göktürk (2017) kadın futbolcular, Gülen ve diğerleri (2017) Taekwondocular; Yerlikaya (2019) bisikletçiler üzerine araştırmalar yapmışlardır.

Yapılan analizler sonucunda antrenörlük, hakemlik süresi ve hakemlik brövesi açısından farklı olan gruplar arasında işe adanmışlık ve alt boyut puanları açısından istatistiksel olarak anlamlı farklılık bulunmamaktadır (Tablo 7, 8, 9). Adanmış bireylerin duygusal olarak, enerjik, heyecanlı bir şekilde çalışması; fiziksel olarak tüm enerjisini işi için kullanması; bilişsel olarak ise, dikkatini, aklını işine vermesi nedeniyle çalışma süresi ve kıdem değişkeninin çalışanın işe adanmışlığının seviyesini etkilemediği söylenebilir. Literatürde farklı mesleklerde işe adanmışlık üzerine yapılan çalışmalarda çalışma süresi ve kıdem değişkenleri açısından ortak bir yargının oluşmadığı farklı sonuçlara ulaşıldığı görülmektedir. Aktaş ve Akdemir (2019), Büyükbeşe ve Gökaslan (2018) çalışmalarında işe adanmışlık ile katılımcıların kurumlarındaki çalışma süreleri arasında anlamlı bir ilişkisinin olmadığını tespit etmişlerdir. Canlı (2020) okul yöneticileri ve öğretmenleri, Cengiz, Turgut ve Kabakçı (2016) BESYO öğretim elemanları, Aydemir ve Endirlik (2019) banka çalışanları, Bahadır ve Certel (2016) beden eğitimi öğretmenleri üzerine yaptıkları araştırmalarda da işe adanmışlık düzeyinin çalışma süresi ve kıdeme göre farklılık göstermediği sonucuna ulaşmışlardır. Aslantaş (2016) çalışmasında 0-5 yıl çalışanlar aleyhine, 16-20 yıl çalışanlar lehine farklılık olduğunu tespit etmiştir. Vaksalla ve Hashimah (2015) ve Yıluzar (2016) çalışmalarında sağlık çalışanlarının meslekte çalışma sürelerinin işe adanmışlık boyutlarından enerjiklik ve yoğunlaşmayı etkilediğini, işinde en yüksek enerjiye sahip bireylerin örgütlerinde 6-10 yıl ve 10 yıldan fazla, en düşük enerji seviyesinde olanların ise 1 yıldan az çalışmış olduğu sonucuna ulaşmışlardır. Bir diğer çalışmada Tokmak (2019) 3 yıldan az çalışanların işe adanmışlık düzeylerinin diğerlerine nazaran daha düşük olduğunu bulgusuna ulaşırken Ekinci (2012), Kızıl (2014) ve Zöğ'ün (2007) öğretmenler üzerine yaptıkları çalışmalarda da benzer sonuçlara ulaşılmıştır. Bu bağlamda mesleğe yeni başlayan çalışanların işe adanmışlık düzeyinin düşük olduğu söylenebilir. Öte yandan Aybas (2014) ve Yılmaz ve Keçecioğlu (2018) araştırmalarında örgütte çalışma süresi arttıkça adanmışlık düzeyinin azaldığını tespit etmiştir. Çalışmalarda ulaşılan sonuçlar göz önüne alındığında mevcut araştırmanın bulgularıyla farklılık görülmektedir. Altunel ise (2015) yöneticilerin kariyerlerinin ilk dönemlerinde kendilerini kurumlarına ispatlama sürecine girdikleri için adanma seviyelerinin arttığını fakat daha sonra tükenmişlik yaşadıkları için adanmışlık seviyelerinin düştüğü sonucuna ulaşmıştır. Yapılan ayrıntılı alan yazın taramasında antrenör ve hakemlerin işe adanmışlık düzeyleriyle çalışma süresi ve kıdem değişkenlerini karşılaştıran bir çalışmaya rastlanamamıștır. Araștırmanın bu yönüyle alan yazına katkı sağlayacağı düșünülmektedir

Sonuç olarak, elde edilen araştırma bulguları ışığında sonuçlar özetlendiğinde; hakem olarak da görev yapan antrenörlerin işe adanmışlık seviyelerinin yüksek düzeyde olduğu ve toplam çalışma saati, mesai dışında çalışma durumu ve sosyoekonomik düzey değişkenlerinin işe adanmışlık düzeylerini belirlemede önemli rol oynadığı söylenebilir. 
Günümüzde artarak devam eden uluslararası müsabakalarda elde edilen büyük başarıları sayesinde Türk cimnastikçileri dünyanın en gözde, en başarılı cimnastikçileri arasındadır. Bu büyük başarılarda çok uzun yıllar cimnastik sporuna kalbini koymuş, antrenör ve hakemlerin önemli role sahip oldukları söylenebilir. Bu yüzden sporun temel taşı olan antrenör ve hakemlerin işlerinde daha yüksek performanslı, tüm enerjilerini kullanarak çalışması için işe adanmışlık kavramı spor kulüpleri, spor federasyonları ve spor yöneticileri gibi iç ve dış paydaşlar tarafından da önemsemesi gereken bir konudur.

Adanmışlığa sonsuz bir süreç olarak bakılması nedeniyle devamlı yöneticiler tarafından takip edilmesi, işe adanmışlıktaki artışın iş sonuçlarına olan etkisinin değerlendirilmesi gerekir (Yılmaz ve Keçecioğlu, 2018). Bu noktadan hareketle; çalışanların işe adanmışlık duygularının artırılması için yöneticilerin adaletli bir yönetim anlayışı ile yaklaşması ve çalışanların işe daha fazla adanmalarını sağlayacak ücretle ilgili düzenlemelerin yapılması önerilebilir. Bununla birlikte yapılan araştırma sonucunda, antrenör ve hakemlerin işe adanmışlıklarına ilişkin literatürde herhangi bir çalışmaya rastlanılmamıştır. Bu nedenle çalışmanın sonuçlarının alan yazının zenginleşmesine, spor bilimleri alanında insan kaynağının geliștirilmesine ve daha verimli, enerjik çalışması için yapılabileceklere katkı sağlayacağı düşünülmektedir.

\section{Yazar notu:}

$\mathrm{Bu}$ araştırmanın bir kısmı, 22-23 Mayıs 2021 tarihinde online olarak düzenlenen 4. Uluslararası Herkes İçin Spor Kongresi'nde sözel bildiri olarak sunulmuştur.

\section{Çıkar Çatışması}

$\mathrm{Bu}$ makalenin yayınlanmasıyla ilgili yazarlar arasında herhangi bir çıkar çatışması bulunmamaktadır.

\section{Yazar Katkıları}

Araştırma Fikri: BG, AAY; Araştırma Tasarımı: BG, AAY; Verilerin Analizi: BG; Makale Yazımı: BG, AAY; Eleştirel İnceleme: AAY

\section{Yazışma Adresi (Corresponding Address):}

Öğretim Görevlisi Banu GÜNDOĞAN

Avrasya Üniversitesi, Egzersiz ve Spor Bilimleri Bölümü, TRABZON

ORCID: 0000-0001-6434-4118

E-posta: banugundogan0@gmail.com 


\section{Kaynaklar}

1. Aktaş, K. ve Akdemir, B. (2019). İş görenlerin adanmışlık düzeyi ve örgütsel özdeşleşme ilişkisinin performans algısına etkisini belirlemeye yönelik bir araștırma. Sosyal Siyaset Konferansları Dergisi, 77, 307-348.

2. Altunel, A. T. (2015). Örgütsel güven düzeyi ile örgütsel adanmışlık düzeyi arasındaki ilişsi: bir araştırma (Yüksek lisans tezi). İnönü Üniversitesi Sosyal Bilimler Enstitüsü, Malatya.

3. Aslantaş, M. (2016). Yetenek yönetiminin işe adanma, performans ve ișten ayrılma niyetine etkisi: Bankacllık sektörü örneği (Doktora tezi). Dicle Üniversitesi Sosyal Bilimler Enstitüsü, Diyarbakır.

4. Aybaş, M. (2014). Insan kaynakları uygulamalarının çalışanların işe adanmışlığı üzerindeki etkisi ve pozitif psikolojik sermayenin aracı rolü konuya ilişkin bir araştırma (Doktora tezi). İstanbul Üniversitesi Sosyal Bilimler Enstitüsü, İstanbul.

5. Aydemir, C. ve Endirlik, H. (2019). İșe adanmışlığın bazı demografik değişkenler açısından incelenmesi: Bankacıllk sektöründe bir araştırma. Atatürk Üniversitesi Sosyal Bilimler Enstitüsü Dergisi, 23(3), 1093-1107.

6. Aydemir, S. (2018). Örgütlerde mesleki bağlllı̆̆ı ișe adanmışlık üzerindeki etkisine yönelik bir araștırma. Turkish Studies, 13(18), 207-223.

7. Bahadır, Z. ve Certel, Z. (2016). Beden eğitimi öğretmenlerinin örgütsel sessizlikleri ile örgütsel adanmışlıklarının incelenmesi. Ahi Evran Üniversitesi Kırșehir Eğitim Fakültesi Dergisi, 17(1), 135146.

8. Bakker, A. B., Schaufeli, W. B., Leiter, M. P. ve Taris, T. W. (2008). Work engagement: An emerging concept in occupational health psychology. Work \& Stress, 22(3), 187-200.

9. Bal, E. (2008). Self-efficacy, contextual factors and well-being: The impact of work engagement (Doktora tezi). Marmara Üniversitesi Sosyal Bilimler Enstitüsü, İstanbul.

10. Bal, E. A. (2009). Gönülçelen şirketler. İstanbul: Beta Basım.

11. Barutçugil, İ. (2002). Performans yönetimi. İstanbul: Kariyer Yayıncllık.

12. Bersin, J. (2015). Becoming irresistible: A new model for employee engagement. Deloitte Review, 16, 147-163.

13. Büyükbeşe, T. ve Gökaslan, M. (2018). İșe gömülmüşlük, işe adanmışlı ve işten ayrılma niyeti ilişkisi: Bir alan çalışması. Mukaddime, 9(2), 135-153.

14. Canlı, M. (2020). Okul yöneticileri ve öğretmenlerin öğretmenlik mesleğine adanmışlık düzeyleri (Tezsiz yüksek lisans projesi). Pamukkale Üniversitesi Eğitim Bilimleri Enstitüsü, Denizli.

15. Cengiz, R., Turgut, M. ve Kabakçı, A. (2016). BESYO öğretim elemanlarının adanmışlık düzeylerinin belirlenmesi. International Journal of Sport Culture and Science, 2(1), 582-593.

16. Cohen, R. J. ve Swerdlik, M. (2010). Psychological testing and assessment: An introduction to tests and measurement (7th ed.). New York: McGraw Hill.

17. Çetin, F., Basım, H. N. ve Aydoğan, 0. (2011). Örgütsel bağlılığın tükenmişlik ile ilişkisi: Öğretmenler üzerine bir araştırma. Selçuk Üniversitesi Sosyal Bilimler Enstitüsü Dergisi, (25), 6170.

18. Demir, A. (2020). İlkokulda çalışan öğretmenlerin örgütsel adanmışlıkları ile iş doyumları arasındaki ilişki (Tezsiz yüksek lisans projesi). Pamukkale Üniversitesi Eğitim Bilimleri Enstitüsü, Denizli.

19. Durgut, A. İ. ve Günay, G. Y. (2020). Etik liderlik, işe adanmışlık ve yönetsel yaratıcllık arasındaki ilişski: Yapı malzemeleri sektöründe bir uygulama, Journal of Organizational Behavior Review, 2(2), 149-171.

20. Ekinci, Ö. (2012). Ortaöğretim okulu öğretmenlerinin yıldırma davranışları ile örgütsel adanmışlıkları arasındaki iliş̧ki (Yüksek lisans tezi). Necmettin Erbakan Üniversitesi Eğitim Bilimleri Enstitüsü, Konya. 
21. Eryılmaz, A. ve Doğan, T. (2012). İş yaşamında öznel iyi oluş: Utrecht işe bağlllık ölçeğinin psikometrik niteliklerinin incelenmesi. Klinik Psikiyatri Dergisi, 15(1), 49-55.

22. Göktepe, E. A. (2016). Yeni kariyer tutumları, algılanan yönetici desteği ve ișe tutkunluk arasındaki ilişki: bir araştırma (Doktora tezi). İstanbul Üniversitesi Sosyal Bilimler Enstitüsü, İstanbul.

23. Güner, H. (2006). Öğretmenlerin adanmışlık sorunu: İstanbul ili örneğinde bir çalışma (Yüksek lisans tezi). Marmara Üniversitesi Eğitim Bilimleri Enstitüsü, İstanbul.

24. Gülen, Ö., Madak, E., Kumartaşıl, M. ve Sönmez, H. 0. (2021). Taekwondo sporcularının spora bağlılık düzeylerinin milli sporculuk durumları ve çeşitli değişkenler açısından incelenmesi. The Online Journal of Recreation and Sport, 10(3), 1-17.

25. Hoş, C. ve Oksay, A. (2015). Hemşirelerde örgütsel bağllık ile iş tatmini ilişkisi. Süleyman Demirel Üniversitesi İktisadi ve İdari Bilimler Fakültesi Dergisi, 20(4), 1-24.

26. Kahn, W. A. (1990). Psychological conditions of personal engagement and disengagement at work. Academy of Management Journal, 33(4), 692-724.

27. Kalaycı, S.. (2009). SPSS Uygulamalı Çok Değişkenli İstatistik Teknikleri. Ankara: Asil Yayın Dağıtım.

28. Karaçam, A. ve Pulur, A. (2018). Basketbol ve futbol hakemlerinin mesleki haz düzeylerinin bazı demografik değişkenler açısından incelenmesi. Spormetre, 16(4), 288-295.

29. Kaygın, E. ve Bağcıoğlu, D. (2018). Çalışanların öz yeterliliklerinin ve esenlik algılarının işe adanmışlıklarına etkisi: İlaç sektörü örneği. Kahramanmaraş Sütçü İmam Üniversitesi Sosyal Bilimler Dergisi, 15(2), 607-626.

30. Kelecek, S. ve Göktürk, E. (2017). Kadın futbolcularda sporcu bağlllığının sporcu tükenmişliğini belirlemedeki rolü. Başkent Üniversitesi Sağllk Bilimleri Fakültesi Dergisi BÜSBID, 2(2), 162-173.

31. Kelecek, S., Kara F. M. ve Aşç, H. (2014). Hakemlerin tutkunluk düzeyleri, iş doyumu ve yaşam doyumunun belirleyicisi mi? Türkiye Klinikleri Spor Bilimleri Dergisi, 6(2), 74-80.

32. Kelecek, S. ve Koruç, Z. (2018). Futbolcuların güdüsel yönelim ve spora bağlılık düzeylerinin sporcu tükenmişliğini belirlemedeki rolü. Başkent Üniversitesi Sağllk Bilimleri Fakültesi Dergisi, 2(2), 102-116.

33. Kızıl, Ş. (2014). Öğretmenlerin duygusal zekâları ile örgütsel adanmışlıkları arasındaki iliş̧i (Balıkesir ili örneği) (Yayımlanmamıș yüksek lisans tezi). Okan Üniversitesi Sosyal Bilimler Enstitüsü, İstanbul.

34. Kozikoğlu, İ. ve Özcanlı, N. (2020). Öğretmenlerin 21. yüzyll öğreten becerileri ile mesleğe adanmışlıkları arasındaki ilişki. Cumhuriyet International Journal of Education, 9(1), 270-290.

35. Özyılmaz, A. ve Süner, Z. (2015). İșe adanmışlığın işyeri tutumlarına etkisi: Hatay'daki 9 işletmede yapılan ampirik araştırmanın sonuçları. Eskişehir Osmangazi Üniversitesi IIIBF Dergisi, 10(3), 143-164.

36. Polat, C.. ve Örs, S. B. (2018). Ritmik Cimnastik. Ankara: Gazi Kitabevi.

37. Rich, B. L., Lepine, J. A. ve Crawford, E. R. (2010). Job engagement: antecedents and effects on job performance. Academy of Management Journal, 53(3), 617-635.

38. Sarıkaya, B. B. (2016). Otizmli çocuklarla çalışan öğretmenlerin işe adanmışlık, çocuk sevme ve empati eğilimleri arasındaki ilişki (Yüksek lisans tezi). Beykent Üniversitesi Sosyal Bilimler Enstitüsü, İstanbul.

39. Sarıbaş, M., Akça, D. ve Meydan A. (2020). Ücretli öğretmenlerin mesleğe adanmışlıkları. Eğitimde Yeni Yaklaşımlar Dergisi, 3(2), 52-72.

40. Schaufeli, W. B., Salonova, M., Gonzalez-Roma, V. ve Bakker, A. B. (2002). The measurement of engagement and burnout: A two sample confirmatory factor analytic approach. Journal of Happiness Studies, 3(1), 71-92.

41. Schaufeli, W. B., Bakker, A. B. ve Salanova, M. (2006). The measurement of work engagement with a short questionnaire: a cross-national study. Educational and Psychological Measurement, 66(4), 701-716. 
42. Schaufeli, W. B. (2018). Work engagement in europe: relations with national economy, governance and culture. Organizational Dynamics, 47, 99-106.

43. Sonnentag, S. (2003). Recovery, work engagement, and proactive behavior: A new look at the interface between nonwork and work. Journal of Applied Psychology, 88(3), 518-528.

44. Sönmez, V. ve Alacapınar, F. G. (2019). Örneklendirilmiş bilimsel araştırma yöntemleri. Ankara: Anı Yayıncllık.

45. Şahinbaş, F. (2018). Pozitif örgütsel davranış yaklaşımıyla işyeri arkadaşlığı ve işe adanma iliş̧isi: sağlık çalışanları üzerine bir araştırma (Yüksek lisans tezi). Hacettepe Üniversitesi Sosyal Bilimler Enstitüsü, Ankara.

46. Taşlıyan, M. ve Güler, B. (2020). İșe adanmışlık. M. Ş. Şimşek, A. Çelik, T. Akgemci, A. Diken (Ed.), Örgütsel davranış ve yönetim psikolojisi içinde (s. 254-257-258). Konya: Eğitim Yayınevi.

47. Tokmak, M. (2019). Algılanan üst yönetim desteğinin işe adanmışlık üzerine etkisi: Bir araştırma. Pamukkale Üniversitesi Sosyal Bilimler Enstitüsü Dergisi, 36, 273-290.

48. Turgut, T. (2010). Çalışmaya tutkunluk. G. İslamoğlu (Ed.), Kurumlarda iyilik de var içinde (s. 6566). İstanbul: Nobel Yayın.

49. Vaksalla, A. ve Hashimah, I. (2015). How hope, personal growth initiative and meaning in life predict work engagement among nurses in Malaysia private hospitals". International Journal of Arts \& Sciences, 8(2), 321-378.

50. Yavan, Ö. (2016). Örgütsel davranış düzleminde adanmışlık. Pamukkale Üniversitesi Sosyal Bilimler Enstitüsü Dergisi, (25), 278-296.

51. Yerlikaya, G. (2019). Bisikletçilerin sporcu bağlllıklarının incelenmesi (Yüksek lisans tezi). Bolu Abant İzzet Baysal Üniversitesi Sosyal Bilimler Enstitüsü, Bolu.

52. Yılmaz, M. ve Keçecioğlu, T. (2018). İşe adanmışlık: Mevcut düşüncenin gözden geçirilmesi. Business Economics and Management Research Journal, 1(1), 55-71.

53. Yıluzar, H. (2016). Kişi-örgüt uyumu ile işe adanmışlık ve örgütsel bağlllık ilişkisi: Sağllk sektöründe bir araştırma (Yüksek lisans tezi). Akdeniz Üniversitesi Sosyal Bilimler Enstitüsü, Antalya.

54. Zöğ, H. (2007). İstanbul ili Kağıthane ilçesinde görev yapan ilköğretim okulu öğretmenlerinin örgütsel adanmışlıkları ile iş doyumları arasındaki ilişki (Yüksek lisans tezi). Yıldız Teknik Üniversitesi Sosyal Bilimleri Enstitüsü, İstanbul.

55. Türkiye Cimnastik Federasyonu Bülteni (2020). 18, 5-14. 